\title{
Editorial \\ Ex-territories and Technological Art: An Overview of a Latin American Heritage
}

\author{
Reynaldo Thompson \\ Associate Professor, Department of Art and Management, University of Guanajuato, Mexico. \\ Email: thompson@ugto.mx
}

The word EXTERRATORIALITIES itself brings to mind different historical and contemporary events and facts. On the one hand, we have the exodus expressed in the Bible and on the other, we have contemporary migrations in a more closer knowledge civilization. Migrations is not new, and in order to get a glimpse of some important facts that had shaped the present trajectory of immigration in Latin America, I invite you to read the book The Open Veins of Latin America (1971) written by the Uruguayan journalist and writer Eduardo Galeano (1940-2015). In the book, he briefly but clearly analyzes the history of colonialism and its modern manifests, focusing on the massive exploitation of natural resources during the period of European colonialism and then the American domination of Latin America. In the last century, and because of the wealth of natural resources in Mexico, the country came into conflict with different transnational companies: for instance, before the WWII the oil industry was owned by the Standard Oil and was property of the Rockefellers; it was nationalized by Mexican President Lazaro Cárdenas in 1938. The other industrial house Light and Power, now named Comisión Federal de Electricidad was nationalized in 1937, although before nationalization it belonged to North American companies. Today both enterprises belong to the state, unfortunately with great levels of mismanagement inside. Eduardo Galeano argues in his book that the oil business is run by a powerful cartel established in 1928 by Standard Oil, Shell and British Petroleum, with which Gulf and Texaco joined later.

The phenomenon of migration to the US has an important effect on the Mexican economy. In recent years however, as a result of better performance within the nation and a recognizable growth in investments from Japan, Germany and United States among other countries, and because of more efficient financial institutions within Mexico, the migration from Mexico to the US has been decreasing, as the Pew Research Center in Washington demonstrates. ${ }^{\mathrm{i}}$

Mexican artist, Marcela Armas had reflected on the use of energy (as also petroleum energy) in her artworks by using elements directly related to businesses that extract or exploit natural resources. Marcela's artworks include the use of high voltage power as in Resistencia (2009) or the use of scrap from an automobile in the work now called CeNIT (2007). In her art installations the abuse of natural resources is always in focus. In Resistencia we see a reflection on the use and exploitation of not only electrical energy, but also human energy, implying cheap hand labor.

Resistencia (2009) was put together with a heated metallic wire resistance - one made out of steel chords that seemed to outline the Mexican border with the United States (in recent days

(c) AesthetixMS 2016. This Open Access article is published under a Creative Commons Attribution Non-Commercial 4.0 International License (http://creativecommons.org/licenses/by-nc/4.o/), which permits non-commercial re-use, distribution, and reproduction in any medium, provided the original work is properly cited. For citation use the DOI. For commercial re-use, please contact editor@rupkatha.com. 
the subject is implicated with the polemics of building a wall for which Mexicans would have to pay, as the new president of the US claims). The idea of the border is not only a territorial and a geographical limit; it also represents the limits of the rule of nations confined by its limits. Traditionally and after losing 2.5 millions square $\mathrm{Km}$ in the XIX century to the United States, Mexicans had started emigrating to the US, looking for opportunities of jobs and realizing an American Dream. In Marcela Armas' work Resistencia - the incandescent light of the electrical resistance is so attractive that it invites us to touch it; it appears perhaps like the fatal magnet that invites one to cross the dangerous limits of the border and achieve success and prosperity through work, determination and initiative. Armas' work Resistencia highlights two main circumstances around the subject of the border. First is the idea of national limits, the second is the sizzling subject of an invisible wall between two countries, one the most 'powerful' in the world and the other being the poorer people of Latin America.

Next, in another artwork, called the Cenit the artist projects the exploitation of raw materials, that as we mentioned, are owned by the state. CeNIT (Zenith) consists of burnt-out oil from a car, a catheter and a hydraulic pump. The first object is normally the scrap of an automobile, while the thin plastic hose is usually used in hospitals to provide serum or blood to the patient, and the pump may be a symbol of the heart. In this case, the catheter forms the silhouette of a cityscape, emphasizing on the theme of energy as a source of life for urban areas. The time invested to complete the profile of the city, with the oil in the catheter is 15 hours. At the end of the tour when the scraps shape the cityscape, the burnt oil leaks from a symbolic cargo ship on to the clean white wall of the gallery, which may in turn be a metaphor of the ocean itself. The narrative describes a visual process of energy-exploitation in a metropolis with all its ambitions of power, development and progress. The work of Marcela Armas is just one of the few examples of innovative use of technology in achieving an art, one produced as a representative artistic vision of people living in the south of the Rio Grande.

The emergence of new Media Art in Latin America is an extraordinary heritage but it has been under-represented in the art historical discourse. Power structures operate not only like economies but also in the form of cultural imperialism. Pioneer Latin-American artists have neither been recognized nor absorbed into mainstream literature. Here, I may refer to our heritage preservation project called the Digital Art in Latin America especially oriented toward a perception of a digital art prototype that evolved as a response to infiltrations of technology into Latin America. Our emphasis is first, on the rise of those forms of proto-electronic art in the mid twentieth century in terms, which were initially represented in structural invariances of optical and also pre-digital templates. Leading artists like Julio LeParc (in Argentina) was experimenting with projection of light on reflective materials. In Brazil, Abraham Palatnik tried transpositioning colors through mechanical movements. Waldemar Cordeiro and Otávio Donasci were similar innovators, the first using punch card applications, and the other, video and performance. Chilean Carlos Martinoya and Naum Joel created the Abstratoscopio Cromatico, to anticipate an entirely new artistic usage of polarized light effects, which the world had never witnessed before. In Mexico, Manuel Felguerez, produced innovative pictorial compositions using paleocomputational programming language in an age when the PC was nonexistent. Pola Weiss embraced video art at a time when Nam June Paik was building his installations in North America. She was the first techno artist using video to express her creative concerns; however Weiss did not only embrace Video art, she was also exploring mass media communications like TV in order to engage the viewer with the artwork. Performance was also among her preferred forms. 
The archival project on digital heritage preservation is an attempt to save the history of this transformation in the arts and to restore the place of Latin-American artists in the trajectory. It is an archival project in the making that seeks therefore to set across a view of new age in the arts in the intersection of a new universe. Intersections of art and technology commenced earlier depending on the country under consideration. For instance, Argentina, Chile and Brazil were some of the first countries who started exploring different media related to technology, and filtering out those used traditionally in the visual arts, like canvas and oil on painting or stone and wood in sculpture. Julio LeParc in Argentina produced a large body of work using light projected on different materials such as polished metal, plastic, glass and crystal, all exhibited at the Venice Biennial in 1966. Later and depending on the advances in technology, some artists started incorporating mechanical systems or machines and later electronic components or more complex devices, like computers.

So, even the media as well as the geographic context were diverse yet none of these artists' names are either recognized or acknowledged in books on Western new media history; perhaps we need to follow the aims expressed in Israeli artists Amir and Sela's new book Extraterritorialities in Occupied Worlds.

The project aims [is] not only to draw on existing definitions of extraterritoriality but seeks to reload it with new meaning, searching for ways in which the notion of extraterritoriality could produce a critique of discriminating power structures and rearticulate new practical, conceptual and poetic possibilities. ${ }^{\text {ii }}$

Our idea here is that since we are living in a more inter-related world, art historians and scholars in developed countries may look for different interpretations and forms of art, not only produced within the limits of their nations, but also from more peripheral regions. After all, as Bauman states in the same book I mentioned above, Globalization is nothing more than a totalitarian extensión of their logic on all aspects of life $e^{i i i}$. From that perspective, globalization expresses a high level of cultural imperialism and favors the powerful.

Here I want to go back to the Digital Arts in LatinAmerica (DALA) project that seeks recognition of those pioneers that contributed to the development of contemporary hybridization of art in Latin America but have been systematically neglected and expunged from its rightful place in the universal history of art. In a visualization work by the German scholar Maximilian Schich and his project Humanity's Cultural History Latin America has almost no representation at all when compared to the arts produced in the power enclaves of Europe or the United States. To be more precise it is not only Latin America that is under represented: Africa and Asia - the new giants are all also systematically under-represented. Even in the maps of the UNESCO world heritage sites we discover a real and unforgivable misrepresentation of history and data base, similar to the one Dr. Schich's tends to fallaciously promote. Therefore we have no time to waste if we were to write our own history before its perdition. Yuval Noah Harari states in Sapiens. A brief history of humankind:

There is no evidence that history acts for the benefit of humans because we lack an objective scale on which to measure that benefit. Different cultures define the good differently, and we do not have a definitive yardstick to judge between them. The victors, of course, always believe that their definition is correct. However, why should we believe the winners? ? $^{\text {iv }}$

And as it happens along time, history has mostly been written by those who hold power, however our task may be to preserve the memory of those who oexplored new ways to interpret the world. 
There are already some institutions addressing the issue and investing their resources to save that memory. An interesting case is brought before us in Extraterritorialities in Occupied Worlds, in the work of Victoria Bernal who emphasizes the experience of those not living in their own country, especially at a time when inter-connection in the digital age contributes so enormously to bring people together. Bernal exemplifies with the help of the Eritrean diaspora.

Diaspora possesses no territory; they exist, not through occupying space, but by transcending it. Migrants, refugees, diasporas, and similar populations live in ambiguous and simultaneous relationships with multiple territorial locations and communities. ${ }^{\mathrm{v}}$

In case of the DALA Project, we see that many of the artists that contributed to the development of new pathways in art and technology were artists sometimes living in other countries, especially Europe or the United States; some of others came to Latin America from other countries and established themselves here.

From our perspective it is important to keep trace and memory of all those figures moving out of dominant cultures who as Harari explains may be victims of a new sort of exclusion.

These racist theories, prominent and respectable for many decades, have become anathema both among scientists and among politicians. People continue to wage a heroic struggle against racism without realizing that the battle front has changed, and that the place of racism in imperial ideology has now been replaced by "culturalism." This term does not exist but it is time we invented it. [...] We no longer say: "It is in his blood." Now we say: "It is in its culture". vi

In this exclusionary phenomenon, nationalism has played a key role in dominant Western countries, especially those with strong and powerful economies. Eduardo Galeano explains while focusing on the United States.

The North American feat would have not needed explanation if it had not been animated, from its very beginning, by the most fervent of nationalism. ${ }^{\text {ii }}$

However as Bernal explains by focusing on Eritreans:

Eritrian websites reveal the creativity of the less powerful to construct new spaces and strategies of political participation and to expand the boundaries of what can be publicly expressed. viii

Thus the DALA project may exist in space as a website with no other purpose than to remember those who had opened up new forms of expression in a globalized world, where monoculturalism denies them their own existence. Again Bernal argues:

Websites may serve as extraterritorial when the aspect of virtual space is foregrounded, offering a space that has no particular location but is everywhere and accessible form anywhere. The ambiguity of location on the Internet thus makes possible different forms of territorialization, deterritorialization, reterritorialization and, extraterritoriality. ${ }^{\text {ix }}$

So, the aim of the Digital Arts in Latin America project is to take control of our own history and destiny, artists had demonstrated that creativity and determination to achieve a goal is far more powerful than military methods that governed the subcontinent for many decades. Bernal sees the internet as a tool of liberation - she explains.

Yet the Internet remains an inspiration, stimulating imaginaries of an unbound world where borders are crossed with ease and intimacies transcend distance, where 
collaboration and community persist on the basis of mutual interest rather than on representation, and where new spaces of creativity and connection continue to be sited. ${ }^{\mathrm{x}}$

Like Eritreans who gained independence by uniting themselves against the forces that prevented them to grow, DALA aims for autonomy and awareness of a colonialist era in the art, science and technology.

\section{Notes}

${ }^{i}$ http://www.pewresearch.org/fact-tank/2016/o2/11/mexico-and-immigration-to-us/. Consulted 13 the May 2017. 11.3 millions of undocumented migrans in the US and $50 \%$ are Mexicans.

ii Amir, Mayaan. Sela, Ruti. (2016) Extraterritorialities in Occupied Worlds. Punctum Books. P. 14

iii Ibid. p 77

${ }^{\text {iv }}$ Harari, Yuval Noah (2014). De animales a dioses. Breve historia de la humanidad. Editorial Debate. Mexico. P. 269 My translation: No hay pruebas de que la historia actúe en beneficio de los humanos porque carecemos de una escala objetiva en la que medir dicho beneficio. Diferentes culturas definen de manera distinta el bien, y no tenemos una vara de medir definitiva para juzgar entre ellas. Los vencedores, desde luego, creen siempre que su definición es la correcta. No obstante, ¿por qué habríamos de creer a los vencedores?.

${ }^{v}$ Amir and Sela. P. 188

${ }^{\text {vi }}$ Harari (2014). P. 334. My translation. Estas teorías racistas, prominentes y respetables durante muchas décadas, se han convertido en anatema tanto entre los científicos como entre los políticos. La gente continua librando una lucha heroica contra el racismo sin darse cuenta de que el frente de la batalla ha cambiado, y que el lugar del racismo en la ideología imperial ha sido sustituido ahora por el "culturalismo". Este termino no existe pero ya es hora de que lo inventemos. [...] Ya no decimos: "Está en su sangre". Ahora decimos: "Está en su cultura"

vii Galeano, Eduardo. (1971) Las venas abiertas de América Latina. Colección Alba Bicentenario. Habana, Cuba.

viii Amir and Sela (2016) p.168

${ }^{\text {ix }}$ Amir and Sela (2016) p. 161

${ }^{\mathrm{x}}$ Amir and Sela (2016) p. 170 